\title{
Learning to Use 'Public Space’: Urban Space in Post-Soviet St. Petersburg
}

\author{
Anna Zhelnina* \\ Higher School of Economics in St. Petersburg/St. Petersburg State University, Faculty of Liberal Arts and Sciences, St. \\ Petersburg State University, 190000, St. Petersburg, Galernaya str. 58-60, Russia
}

\begin{abstract}
The article discusses the post-socialist developments of urban public space in St. Petersburg, Russia. The city with a historic center protected by the UNESCO World Heritage status in combination with the Soviet legacy of lack of public participation is facing the problem of public space development. There are two controversial concepts of urban space represented in the public discourse that are analyzed in the article: the concept of a 'museum city' and the 'city for people'. The historic context of transformation (the Soviet period of the strict divide of public and private, and the postsocialist era of individualization and the decay of the public) is used to explain the current debate and difficulties of building an inclusive and tolerant model of public space in St. Petersburg.
\end{abstract}

Keywords: Belonging, 'Europeanization', post-socialist city, public space, St. Petersburg, transformation.

\section{INTRODUCTION}

The term 'public place' is understood as accessible open space, the access to which is not limited by some social or physical barriers [1]. Scholars often see the public space as an essential part of the urban space, where the interaction of strangers and anonymous encounters of city-dwellers become possible. As Lyn Lofland [2] puts it, City life was made possible by an 'ordering' of the urban populace in terms of appearance and spatial location such that those within the city could know a great deal about one another by simply looking'. Thus urban public spaces function as arenas of visual communication of strangers studying and classifying one another. Works by J. Jacobs and W.H. Whyte have formulated the statement of the importance of public space for the quality of urban life, the basic need for the humanistic urban environment, where the interaction among urban dwellers is stimulated and supported, thus providing them with diverse social experience [3-5].

Such arenas also work as spaces of identification and can create a sense of belonging - to the place, to the community, and to the city. Research on Western cities shows the growing importance of the subject for the public discourse: the struggle about the right to the city as well as the problem of privatization of the public areas are strongly connected to the issue of public space, since these are the spaces where inequality, exclusion and lack of participation become visible [6]. Public spaces can also act as spaces for conflict and alienation, e.g. when certain social groups start claiming the priority in using and defining the place [7]. The perception of the 'Other' in the urban public space, power relations also are represented in the dynamics of public space $[8,9]$. One of the main issues for the western discussion is

*Address correspondence to this author at the Higher School of Economics in St. Petersburg/ St. Petersburg State University, Faculty of Liberal Arts and Sciences, St. Petersburg State University, 190000, St. Petersburg, Galernaya str. 58-60, Russia; Tel/Fax: +7(812) 320-07-27;

E-mail: azhelnina@gmail.com the privatization of the public spaces and the social processes leading to it: growing individualism and alienation of urban life $[10,11]$, the shrinking quantity and quality of public places, the appropriation of public spaces by certain social and cultural groups.

How is this problematic relevant for the Russian cases, particularly St. Petersburg, and can the examples from the post-soviet context contribute to the international discussion? After the fall of socialism and the capitalist stabilization, the tendencies of public space development described in the western literature can be observed in Russian cities in an unrestricted form: the extreme privatization, exclusion of the citizens from the decision making regarding the urban space, control of the space by businesses together with the authorities represents the essential features of the post-soviet capitalism. This situation makes it extremely interesting to investigate public discourses and the actual use of the public space by the citizens and their attempt to reclaim the space, or to normalize the situation of its appropriation by the institutions and social groups. The inclusive and exclusive notions of the public sphere [12] are currently opposing each other in the discourse on urban public space in St. Petersburg, posing such important question as, who is to determine the city's development, who 'belongs' to the city, and who is excluded?

The paper addresses the issue of the public space in the post-Soviet city of St. Petersburg; though the term 'public space' doesn't exist in the Russian-speaking discourse. In the official documents (such as the Strategic Plan) it is replaced by the neutral 'open urban space' which has little social connotations, meaning the space with no roof rather than a space of social activities. However, the usage of the 'open urban spaces' in modern St. Petersburg is a very conflicting and publicly discussed issue: on one hand, the squares and parks are crowded by good weather, people lying on grass, eating, and chatting; on the other hand, this picture is often presented by both city officials and some citizens as unacceptable, especially for the historic centre of the 
'Russia's cultural capital' (which is the unofficial title of St. Petersburg). The two concepts are analyzed using the example of emerging public space in St. Petersburg in the 2000s. The research is based on the ethnographic observation in the public places and discourse analysis of the ongoing discussion regarding public space in St. Petersburg, as well as document analysis which is used to reconstruct some historical context.

The assumption of the paper is that the current debate about the 'open space' shows the conflict between the old and the emerging new concept of urban space in modern Russia. The first is the concept of open urban space as a 'postcard' that should represent not the living city and its people, but the official and 'nice' views. The latter vision of the city corresponds with the concept of the "museum city", which is one of St. Peterburg's unofficial titles. The city in this framework is seen as a space to be observed, but never touched or lived. This idea of a museum and a decoration is closely related to the Soviet idea of the open urban space as a stage for rallies and demonstrations organized by the Communist Party, a space which was under permanent control of the officials and didn't 'belong' to the city inhabitants. The second concept has been emerging since last decade and is related to the humanist concept of 'city for the people'. Although not under the name of 'public space', the idea of public places for interaction appears in the media and is often expressed by the citizens. An important impulse for the public space discussion were the protest events in 20112012 that followed the parliamentary and presidential elections in big Russian cities: the issue of the quality of the urban public life, public gatherings and spaces for it was raised by the media and the city-dwellers.

The important framework for the discussion on the future of public space in St. Petersburg is the perception of Europe: the speakers, authors, and citizens refer to 'Europeanness' of the city and 'Europe' as an example one should follow. 'Europeanization' in the context of the paper is not the analytical concept serving to compare the patterns of public space in cities of Europe and the post-socialist developments in St. Petersburg. In the case of St. Petersburg it is a construct used by the city administration and citizens to describe the desirable changes and examples, not the reference to the 'real' Europe in most of the cases. The desire of St. Petersburg to be the most European city in Russia in cultural terms is represented in the discourse by this social construction of 'Europeanness' that includes some generalized image of the West and its best-perceived features. This construct serves for the actors as a means to describe and realize the new reality of the capitalist city, which is different from the Soviet developments and the early period of post-socialism (the 1990s).

The question for the paper is how does the role of the public space transform in the 2000s in the post-socialist city, and how is this change perceived and realized by the inhabitants, is there a sense of 'belonging' to the city spaces? An overview of the historical context of St. Petersburg public space is given below. The current situation is represented by empirical cases and the analysis of the discussion of the role of open urban space in the media.

\section{DUAL CITY SPACE AND LIFE IN THE SOVIET LENINGRAD}

The socialist era changed the balance between the private and public as well as the "nature of public space in Central and Eastern European cities by imploding its share, diffusing its patterns, and curtailing the mix of functions it contained' [13]. A specific mode of urban public space in socialist cities was caused by political, economic and ideological characteristics of the Soviet era, and it had to be revised again after the fall of communist rule in the early 1990s. The capitalistic developments as well as inclusion of the exSoviet cities into the global consumer culture have changed urban policies and everyday life significantly. However, the traces of the 'Soviet past' still shape the modern culture of cities and the citizens' identities.

In the USSR the land - urban and rural - was entirely owned by the state and formally belonged "to everyone" (the same as nationalized industries and institutions). The formal status of the 'common space' however did not correspond with the functionality and use of the most spaces: central squares and streets were intended for the demonstrations and rallies initiated and choreographed by the state power. The public place within this concept was supposed to be a place of collective actions controlled by the authorities [14]. The uncontrolled gatherings of people in the central open spaces were undesirable, and the everyday social interactions of city dwellers were pushed into the private domains - such as kitchens, garages and backyards.

The tangible division of life of the Soviet citizens in two parts - public and private - has become a leitmotif in historical and anthropological research of the Soviet reality $[15,16]$. The open city space thus has become the "no one's space' rather than 'everyone's', because it could not be used freely (one cannot say it was appropriated by elites either, since the elites didn't show their power in public; but one can say, the spaces 'belonged' to the state power, pushing away all 'undesirable' forms of everyday life). However, the city space became a symbolic visual representation of local identities. The unique historic centre of Leningrad (the name St. Petersburg was returned to the city in 1991) that was saved in the heroic years of the Siege during the Second World War has become a very strong symbol - not only for the local inhabitants but also for the whole Soviet Union as a representation of great historic and cultural heritage of the country and the heroic resistance during the Great Patriotic War. The open spaces of the city became a picture, a postcard view and a symbol, while life and interaction were hidden inside the blocks and apartments.

The Norwegian anthropologist F.S. Nielsen has found a spatial metaphor for this duality: prospekt (avenue) as a place which represents civilization, is well-conditioned and taken care for, and dvor (backyard) as a place where people actually live and interact; but dvor is not an open space - it is rather a place hidden from the outsider, an "ungoverned domain" [16]. The general split of life into private and public had spread onto the city space as well. The open spaces of the city did not function as the public places, where stranger interaction and diversity are possible. 
After the fall of the Soviet system, the private-public balance started changing: the role of the open spaces and the backyards had to be reinterpreted again. The changes were caused by global forces, switch from planned to market economy. The city restructuring was pushed on by the new economic and political conditions, but also the peculiarities of local policies and city image making contributed to the reinterpretation of the public spaces and the city identity.

\section{BACKGROUND OF CHANGE IN ST. PETERSBURG: 'EUROPEANIZATION'}

In the post-Soviet era St. Petersburg among many other Russian post-Soviet cities had to develop a new management system and strategy. According to the new regulations of residence registration the propiska system was cancelled: the system that attached people to one place of residence which made it impossible to move and migrate freely around the country. The new law of 1993 'On the right of the citizens of the Russian Federation to freedom of movement, choice of place of residence in Russian Federation' caused the significant growth of the migration flows that transformed the structure of the big cities population strongly. It was accompanied by the intensification of the social problems unemployment, fall of quality of life, marginalization of the population - it was all connected with the general industrial and employment system crisis.

The early 1990s in St. Petersburg were characterized by the attempts of the city administration to cope with the general problems: privatization, search for strategic partners and resources for the budget formation. The politics of the first mayor of the new St. Petersburg, Anatoly Sobchak who occupied this position in 1991-96, was oriented towards the inclusion of the city into the international business networks, had a goal to secure the city's financial independence from the federal centre.

After the cancellation of the rational planning system in frames of the planned economy, the state administration authorities lost their position as the only subject of decisionmaking regarding the city development process. The important feature of this period is the appearance of a new agent - the investor. The big financial groups from different areas of business that were ready to invest in the development of the urban territories, placing the capitals in the particular district, started influencing the landscape of St. Petersburg significantly. The problem of privatization of public spaces first appeared in the post-Soviet city: after being 'no one's land' and 'a view' for several decades the centre of St. Petersburg became a huge uncontrolled market space - many kiosks, small shops and street trade occupied all available spaces. In other cases such privatization could be observed as a reduction of public space in the capitalist city [13]. However, in Leningrad-St. Petersburg this logic is not completely applicable: there was no public space in the form of lively interactive places in the central squares and streets, the space was not used as public, but only imagined and interpreted as a common symbol; in the 1990s, however, people started using it - by taking part in street retail and the accompanying processes.

It is possible to say, that in the late 1990s - early 2000s the first centralized, initiated by the city administration, attempts to create public places were made, although not completely deliberate and consistent. They were a result of the reconstructions and renovations of the central spaces and building that were taken in the framework of the $300^{\text {th }}$ City Anniversary preparation and Vladimir Yakovlev government (1996-2003). The renovation and creation of pedestrian zones and public places became a part of the 'Europeanization' of the city - that was an economic strategy as well as the ideology of the urban space transformation on the edge of centuries In other words, from an economic perspective the pedestrian streets are more attractive for businesses such as retail and public catering, the rent and the income of the city rise respectively; and ideologically the renovation allows to reproduce the values of 'Europeanness' and well-being.

By the late 1990s the city infrastructure was in a very poor condition: transportation, housing were near to collapse, the historic city center that was included in the UNESCO World Heritage list in 1991 fell into decay and started gradually losing its 'postcard look'. The necessity to pay attention to the city economy and services became part of the election programme of Vladimir Yakovlev, who became governor by emphasizing his interest to the 'routine work on improvement of the city' [17]. The improvement (blagoustroistvo) of the whole city space is indeed the main feature of the Yakovlev's government. In 1996-97 the Strategic plan of the city development is elaborated, that includes main principles of the city politics [18]. Among them - improvement of the quality of life and creating the attractiveness of the city for investors.

Attracting the investments is viewed as one of the key conditions of the transition of St. Petersburg to the stable, sustainable development. To reach the goal 'favourable economic conditions' had to be created, the city space had to be brought to certain standards, have better infrastructure, and provide the possible investors with easy and transparent real estate market. In general the late 1990s are characterized by realization of big projects in the sphere of urban infrastructure improvement.

The most active reconstructions were performed on the threshold of the $300^{\text {th }}$ Anniversary of St. Petersburg in 2003; that indeed became a turning point for the city. Officially the preparation started in 1999, and in several years there were many big projects of reconstruction and new construction performed. The construction of the new image of St. Petersburg accompanied the reconstruction of the physical space. The work on the image of the city as the "most European city in Russia', as the 'cultural capital' was part of the advertising campaign meant to attract international investment to the city - following the task to "promote the city on the international level' formulated in the Strategic plan [18].

The preparation for the Anniversary was financially supported by the federal budget. The $300^{\text {th }}$ anniversary of St. Petersburg was positioned as an event of international scale. Among the greatest projects performed during the preparation to the Anniversary is the modernization of the 'Pulkovo'-airport, construction of the new Ladozhsky railway station, restoration of the main sights in the city, modernization of the road and transport system (building of the circular highway, etc.). Among the projects were also 
numerous improvements of the open urban places, reconstructions of parks, streets, squares and yards.

The reconstruction of the physical space was accompanied by the work on the new city image, ideology of 'Europeanness' (evropeiskost) was meant to be the distinctive feature of St. Petersburg among other Russian cities. The Strategic plan includes the idea of incorporating the city into the European context as a guideline for the city strategy: first of all, meaning the integration into European economy and trade as a junction of the international trade between Russia and the EU [18].

However, the 'Europeanness' is not reduced to the economic strategy: it is also a guideline for the everyday life of the city-dwellers. The next governor of St. Petersburg, Valentina Matvienko in her pre-election speeches referred to the idea that St. Petersburg should become a city with the 'European life standards'. This ideology was also included into the General Plan of the city (2005, edited in 2008):

'In the basis of the town-planning transformations that are outlined in the Concept of the General Plan of St. Petersburg lies the idea of the 'Open European city'. St. Petersburg must take an appropriate place in the constellation of the great cities of Europe. The new General plan of St. Petersburg is oriented towards achievement of the European standard of the urban environment quality.' [19]

The idea of St. Petersburg as a European city is shared by the authorities and the inhabitants. The ideology of the 'cultural capital' had a goal to 'elaborate a positive image of the city, attract tourists and use the $300^{\text {th }}$ Anniversary as an occasion for receiving donations and credits from the federal center and abroad' [20]. Moreover, the 'Europeanness' becomes the standard to compare with the realities of the post-Soviet St. Petersburg:

'Europe" is invisibly present in all the activities regarding urban transformations. The often used word 'improvement' ('blagoustroistovo') as well as all the innovations in the town planning - pedestrian streets, ball-shaped fountains, modern sculpture - remind one of the 'European standard'[20].

However the Europeanization of St. Petersburg was superficial - or, as the journalist Arkadij Ippolitov metaphorically puts it, it was 'Europe on the bullshit' [21]: it remained on the level of design and visual representation of the 'postcard look', not offering new ideologies and strategies for the city development that could become the basis for the substantial transformation, citizens' involvement in the planning process, neither did it change the concept of the public space to a more 'inclusive' mode.

\section{PUBLIC VS OPEN SPACE}

The development of the public places of St. Petersburg is a good example of such a discrepancy of the 'European image' of the city as well as the changing interpretation of the public space. As mentioned above, the space of the Soviet Leningrad split in two parts - the official 'view' and the everyday life inside the quarters. This situation changed as a result of the described 'Europeanization' policies and the general logic of the post-Soviet city development, but the Soviet and the updated ('europeanized') interpretations coexist in the modern discourse and use of public spaces, showing the still existing conflict of the transforming identities.

First of all, it is important, that in the official documents public places are usually referred to as 'open urban spaces' which has little social connotations, meaning the space with no roof rather than a space of social activities. The notion of the urban public space in St. Petersburg is mentioned and conceptualized in the Chapter 11 of the Decree of the St. Petersburg Government № 1681 «On the St. Petersburg Strategy of Cultural Heritage Preservation». This document contains two different approaches to the urban space: first, the ideas of public space as important communicative part of the city environment, which plays a significant role for the identification of city-dwellers; second, the idea of the open spaces as the 'museum under the sky' that has to be treated respectively (the historic center of St. Petersburg has the status of the UNESCO World Heritage, it is a territory of 26000 hectare; the protected status as well as the harmonious urban landscape have caused the city's unofficial title 'museum under the sky'):

'The improvement of the open spaces, the museification of the archeological objects and small architectural forms improves the quality of life in the city in general.'

On the other hand:

'...they play the main role in providing the recreational and leisure needs of the city community, they are important for the social interaction. The open spaces reflect the collective life of the city; they are a kind of a public living room ('gostinaya') of St. Petersburg. They have a commercial value, and help the economic revival not only by creating the working places, but also by raising the city attractiveness for business investments and living.' [22]

The logic of the document is rather contradictory: the idea of the collective everyday use of the open spaces and the idea of museification appear difficult to combine in practice. The fact itself that the conceptualization of the term 'open urban spaces' and their role for the city society are placed into the document on cultural heritage preservation strategy shows that the perception of those spaces as a visual image, 'a view' dominates over the idea of the space of social communications. Also the term 'living room' (gositnaya) mentioned in the above cited text highlights the space which has to be kept in order to be shown to the guests, but it is not the space of everyday routine use.

During the preparation for the $300^{\text {th }}$ Anniversary, the open spaces of the city attracted the attention of the administration: the improvement of the quality of the urban environment included the creation of open spaces with respect to the 'European traditions'. In the historic city centre and nearby a programme of creating pedestrian streets was implemented, and several zones were indeed 
established. However, the programme was not completely fulfilled, because in the city with the sharpening traffic problem the closure of streets for cars appeared to be a complicated task. Another argument against continuing the programme was the cost of street maintenance that had to be paid from the city budget. As a result, the equipment of the public places in St. Petersburg did not go farther than designing several pedestrian streets (among which the Malaya Konyushennaja and Malaya Sadowaya streets, and some others), and the public space in St. Petersburg happened to be an aesthetic, visual concept rather than a functional one oriented towards providing an interactive and comfortable environment.

\section{BEING CIVILIZED AND BEING 'EUROPEAN': INTERPRETATIONS OF PUBLIC PLACES}

Thus, the 'Europeanization' of the open urban spaces was not consistent. After the celebration of the $300^{\text {th }}$ Anniversary and showing the renovated St. Petersburg to the international and Russian public the public places did not all keep their public character. In a short while after the celebration some of the 'improved' public parks were closed for public: in this way they were cheaper and convenient to be kept 'in order'. There are only a few examples of this kind, but the conflict of the different perceptions of the 'city as a museum' and city for people is a very characteristic feature of the recent developments in St. Petersburg. The image of the city as a 'museum under the sky' mentioned above requires the restrained and respectful behavior from the 'visitors'; no one can live in the museum, no everyday communication is allowed in the museified space. While the idea of the 'city for people', on the opposite, gives priority to the selfexpression of citizens, their everydayness, communication, as well as negative features accompanying this free interaction - possible presence of undesirable others and forms of behavior one does not accept. In the framework of this discussion different models of public behavior are formulated and connected to the different publics; these models correspond with different visions of the city - either as a lived 'Europeanized city' of the 'museum city'. Each of the visions has a different idea of the public that 'belongs' to the central public spaces of the city.

The open spaces, their outfit and use are often an issue of discussions bringing together the opposite points of view on St. Petersburg as a city-museum and city for people. The first one reminds us on the Soviet model of interpreting the open spaces of the city centre as a visual symbol, the other one is an updated version of seeing and using the open spaces as public places, places of interaction and leisure.

Those two points of view can be traced on example of the discussion regarding the reconstruction of one of the most centrally located public gardens - in front of the Kazansky Cathedral on Nevsky prospect. This little garden, consisting of a lawn, fountain, benches, bushes and flowerbeds, was improved for the $300^{\text {th }}$ Anniversary celebration, but was fenced in and closed for public soon after the celebration. The fences were removed only 2007 after the complaints of the citizens. However, in 2009 the fences were back again because people started lying on the grass and walking right on it, thus damaging the lawn. The main opposition to such usage of the space was the representatives of the Russian
Orthodox Church, owners of the Cathedral, who did not enjoy such a neighborhood of the Cathedral with the 'misbehaving' people [23]. The position had support among some of the citizens, for whom the uninhibited use of the public space contradicted the image of St. Petersburg as a museum. The adherents of this position appeal to this 'museified' image of the city and protest against violations of the rules of 'public propriety' and restraint. Among those violations are: lying on the grass, drinking and eating as well as expressive communication, kissing and hugging in public. It is important to emphasize that those expressing this opinion are not necessarily religious: the main protest comes not from the religious norms, but is rather caused by the specific idea of behaving in public, of the inadmissibility of private activities in public spaces that could damage the 'postcard' and great view of the 'gala' St. Petersburg.

An interesting discussion regarding the closure of the public garden [24] took place in the St. Petersburg community of the blogger platform 'LiveJournal', which is the most popular in Russia.

The fact of the relaxing people being in the city landscape displeases some city-dwellers:

'We'd better have a meter-high cast-iron fence there than all this meat.'

To explain their dissatisfaction the protesters against such usage of the city gardens and lawns appeal to the idea of 'civilization':

"Those who are civilized - they'd never loll about near the prospect and suck beer" [24].

The opposite point of view protecting the right of citizens to relax in the fresh air refer to the image of the 'European city', claiming that in all the European cities people lie on the grass in the green areas of the cities. Thus, if St. Petersburg is a European city, public spaces should be freely used by the citizens. The statements of the opponents to the garden closure often used comparisons with the European and North American cities:

'Petersburg is a window to Europe. So the people relaxing on the grass - it is the usual European thing';

'People want to live normally, the living standards are growing little by little, people see how it is all made in the West, and it is understandable that they want it to be so well in their homeland, too' [24].

So, the European image of St. Petersburg is shared by the media discourse and the people's perception, but the idea of 'Europeanness' among the city-dwellers is not uniform.

For the supporters of the garden closure 'Europeanness' is 'civilization', meaning restrained behavior in public places. The inhabitants of St. Petersburg are blamed for not being able to behave 'civilized', therefore there's a need of formal restrictions and regulations of access.

'I'd like it so, that the people would realize it for themselves that this particular Russian lawn is not for lolling about. But even if we are here all such conscious persons, there are still some people treating the public places as 
hooligans and bare consumers. Evidently, we cannot change it, because even if there are normal people here, there is still always much more of cattle (bydlo)' [24].

The personal qualities and behavior of the public place users, the visual image they create contradicts to the image of the 'cultural capital' and 'Russian Europeanness'. The supporters of this point of view prefer the image of the 'gala' (paradnyj) St. Petersburg, an estranged city that can only be observed from the side, but not used:

'Many people would prefer seeing the green grass, although behind the fence, that a dirty hangout-place, even if the latter is the 'best European tradition'.'

This conflict of different images of the city shown on example of one public place is a general contradiction of the post-Soviet St. Petersburg perception in general. First position is oriented towards the 'European lifestyle', the idea that includes active communication and self-expression in public places, prioritizes the interests and comfort of the city-dwellers. The opposite point of view sees the open public space as object of visual delight, a representation of cultural and historic heritage of the city, but not the living environment. The latter point of view has deep roots and is connected with the Soviet tradition of the gap between public and private, of interpreting the city space as not a living space, but a decoration and symbolic landscape. The Soviet concept of the public place (obschestvennoe mesto) ruled out the confluence of public and private, did not stipulate any expressions of individuality in public. It is the unacceptable - from the Soviet point of view - penetration of the private into the public that makes some of the citizens protest against the picnicking on the lawns in the city center. Another peculiarity of the post-Soviet city is the perception of the public places as dangerous - often they are perceived to be used by marginal people: alcohol and drug addicts, homeless people. The perception of the strangers as others in the urban space has a negative connotation (e.g. the people on the lawn in front of the Kazansky cathedral were called 'cattle' (bydlo) by one of the discussion participants. That is however part of a general problem: absence of the habits of diversity, when the different lifestyles in public places are automatically perceived as alien and hostile.

The sharpness of the contradiction between the interpretations of the open urban spaces and the styles of behavior practiced there is partly connected with the novelty of the spatial format itself: the pedestrian streets are a new phenomenon for the post-Soviet city. That stimulates a new type of being-there and communication - observing the others, not just passing by. This type of behavior gradually spread on other suitable spaces - gardens, lawns and embankments. But the novelty of such usage of the spaces causes the rejection among part of the citizens, while the other part appropriated the new spaces and models of behaviour in the city, trying the new 'European' image of the city.

\section{AN EXAMPLE: PEDESTRIAN STREET MALAJA SADOWAJA - HOW IT WORKS IN PRACTICE}

An example of a 'Europeanized' public place in St. Petersburg is the Malaja Sadowaja (MS) pedestrian street. The street was designed, renovated and closed for cars in
1999; it was one of the first and most successful projects dedicated to the $300^{\text {th }}$ Anniversary. The project was also economically very successful - the income of the shops on the street grew 10-fold (it was followed by the increase of rent price and change of the tenants). The street was soon included by the travel agencies into a special route 'European St. Petersburg', showing it to predominantly Russian tourists as an example of a 'European street'.

The reconstruction, however, also provoked a discussion with the same argument: the street design was rated by some experts and citizens as not suitable for the historic centre. However, a significant part of opinion was positive: people enjoyed cleanliness, benches to sit down and the absence of cars. Regardless of the discussion, the street became very popular - in sunny days it is crowded, and even in cold weather there are people. The built environment of the street represents the idea of a 'European' city: it has benches, sculptures, lights, and a sophisticated ball-shaped fountain. All that provokes interest and communication: people make photos with the sculptures, throw coins to some of them, try to turn the ball of the fountain, and interact. The atmosphere on the street allows people to be less reserved, and communicate - visually and verbally. Although in most cases the communication with strangers is reduced to see and be seen. The demonstrative loud laughing and talking, kissing is usually observed on the street. The street is also perceived as a safe place - unlike most streets and squares with traffic, MS is full of children who are let running without permanent presence of an adult nearby. The street performers also like the street - it is a stage for musicians, jugglers, dancers, etc. A good sign is also the presence of single people, sitting and observing the environment and other people. The street is used by a very diverse public different age, gender and well being.

However, the picture is not at all idyllic. From the very beginning of the new history of the MS a significant part of the activities was connected with consumption notably drinking and eating. No surprise, that in a short while most of the shops changed to cafes with a much higher prices than before. So the street experienced a classic problem of public spaces in the capitalist cities: privatization and commercialization $[7,25]$. In recent years during the warm season almost all the space of the street is occupied by the summer terraces of the cafes, leaving almost no place for other activities but visiting the cafes.

The occupation of the public spaces with cafes and advertisement boards, however, does not provoke such discussion and protest as the presence of people and their private activities in the public places. So far protest movements regarding public place in St. Petersburg emerged only in the situations, when a public garden or other territory perceived by the local inhabitants as their own was threatened to be destroyed in favour of a new infill construction. Another issue for protests is the violation of the historic landscape of St. Petersburg by new constructions or demolitions, threatening the heritage status of the city. The quality of the urban environment, however, is seldom on the agenda. The right of the city-dwellers to the city and its 'open'/ public spaces is not yet apprehended by the citizens dominated by aesthetic and private considerations, not the public ones. 


\section{PROTESTS, OCCUPATIONS, AND THE PUBLIC SPACE}

Important developments of the subject followed after the 2011 protest activities caused by the December Parliament elections and March President elections. The difficulties the protesters faced in their attempts to make their discontent visible by gathering in central urban places provoked the growth of interest and discussion regarding the public space of the cities. Though the connection between the discussion about public spaces in the post-Soviet city described above in the article and the recent protests may not seem obvious, the link exists: after the protests several important articles about 'Cities and Protest', 'Urban revolution in Russia' as well as 'Right to the city' appeared in mass media [26-28]. The general interest to urban issues has also grown: researchers within urban studies have suddenly become highly demanded specialists who are asked for expertise and comments in the media. The term 'public space' starts to be more used in the media and social networks as a representation of the general problems of power inequality and political struggle.

The protesters organized public gatherings on central squares of the cities that were not 'approved' by the administration. The arrests and trials over the activists accused of participation in the 'not approved' public events caused an active discussion about citizens' right to use the space of the city, and about public life in general.

The media and the bloggers found out that the citizens are not free to access and use urban squares; and due to this fact the citizens' right for public expression is limited. The discussion about public space in Russian cities raised the question of what is the priority in using the urban space: citizens' will expression or the 'routine' practices (such as going out, shopping, walking in the city) that can be disturbed by the protest actions? Another subject for discussion was the 'lack' of suitable places for the big gatherings. The negotiation between the protest rallies organizers and the city administration about the place for the rally was conflicting and emotional: while protesters tried to take the symbolically important central squares of cities (particularly Moscow and St. Petersburg), the city administration wouldn't approve rallies in the cities' core and tried to move them to the symbolic margins of the urban space - to make the actions less visible and accessible. In case the citizens refused to obey and still gathered in the public spaces they've chosen, the police would start arresting the participants.

There is however another important question that was put on the discussion: the quality of the public life, the 'lack' of urban spaces for face-to-face communication that is replaced by the online social networks. As one of the analytical articles puts it, the activists who came to the protest actions were a 'society of the anonymous revolutioners' [29] people never met before and will never meet afterwards because the only public place they had so far is the space of the Internet, and the urban public space is not yet perceived as a real communication opportunity. The protest actions can thus cause a significant reinterpretation of the role of the urban space as a space for public life, and further transformation of the public space concept.

\section{CONCLUSIONS}

The popular perception of the open spaces in St. Petersburg is that they are rather a cultural value, a representation of the past, history, and cultural heritage. They have an important symbolic value and are a basis for a sense of belonging to the city - however, they also can be a cause for exclusion of certain social groups from this right to belong. The conflict of interpretations of the public space (as a space to live in and to use for everyday interactions $v s$ a museified symbolic value) represents the conflict of different ways of belonging to the city. In the discourse this problem is formulated in many discussions on "what is the St. Petersburg way' of treating the open spaces. The construct of 'Europe' used as a reference for the desired developments also helps to manipulate identities and belonging.

Nevertheless, the public places exist and are produced by the activities of people, although not existing as a value and a right of citizens. The ongoing discussions show two contradictory points of view. The first, 'post-Soviet' point of view does not allow the confluence of private and public in the open spaces, protecting the symbolic space of St. Petersburg from everyday penetrations. The second, emerging 'Europeanized' point of view assumes the everyday appropriation of public space of the city to be the right of citizens. This shows the slow transition from the Soviet model of a dual city where private and public life were strictly separated, to a model of a city with public space being appropriated and used by people in their daily life.

Interestingly, this situation somewhat differs from the observations made in the cities of Central Europe [13], where one of the features of transition to capitalism was the reduction and fragmentation the public space. Of course, in St. Petersburg there's also a tendency of exclusion and spatial separation of different social groups, however, it is possible to say, that comparing with Leningrad, where the public space was reduced in its functionality, repressed by the state power control, in St. Petersburg a new perception and interpretation of the city space is forming: that includes appropriation of the open spaces by the city-dwellers, who start claiming their right for it. The means of appropriation are different: hanging out in open spaces, organizing thematic excursions and walks, flash mobs (a new form of protest in Russia, used in case of prohibition of the official protest action, usually involving some artistic forms of expression), etc. However, since recent years the free use of open spaces is getting again complicated by the political situation in the country - public gatherings and activities are often interpreted as a threat and driven away by police.

\section{CONFLICT OF INTEREST}

The author confirms that this article content has no conflict of interest.

\section{ACKNOWLEDGEMENTS}

Declared none.

\section{REFERENCES}

[1] Wüstenrot S, Ed. Jugendliche in öffentlichen Räumen der Stadt. Opladen: Leske Budrich 2003.

[2] Lofland LH. A World of Strangers. New York: Basic Books 1973.

[3] Jacobs J. The Death and Life of Great American Cities. New York: Random House 1961. 
[4] Whyte WH. The Social Life of Small Urban Spaces. Washington, DC: The Conservation Foundation 1980.

[5] Whyte WH. City. Rediscovering the Center. NY: Doubleday 1988.

[6] Marcuse P. From Critical Urban Theory to the Right to the City. City 2009; 13 (2-3): 185-97.

[7] Mitchell D. The end of public space? people's park, definitions of the public, and democracy. Ann Assoc Am Geog 1995; 85 (1): 108-33.

[8] Deutsche R. Evictions: Art and Spatial Politics. In: Bridge G, Ed. The Blackwell City Reader. London: Blackwell 2002; pp. 401-10.

[9] Zukin S. The Cultures of Cities. Cambridge, Massachusetts, Oxford: Blackwell 1995.

[10] Sennett R. Flesh and stone: the body and the city in western civilization. Norton 1994

[11] Sennett R. The Fall of Public Man. Knopf 1977.

[12] Goheen PG. Public space and the geography of the modern city. Prog Hum Geog 1998; 22 (4): 479-96.

[13] Stanilov K. Democracy, markets, and public space in the transitional societies of Central and Eastern Europe. In: Stanilov K, Ed. The Post-Socialist City: Springer 2007:pp. 269-83.

[14] Engel B. Public Space in the Blue Cities in Russia. Prog Plan 2006; 66 (3): 147-237.

[15] Boym S. Common places: mythologies of everyday life in Russia. Harvard University Press 1994.

[16] Nielsen FS. Glaz buri [The Eye of the Whirlwind]. SPb. Aleteja 2004.

[17] Pochemu proigral Anatolij Sobchak [Why Anatolij Sobchal lost]. Kommersant 1996; 21 (180). 11 June

[18] Strategicheskij plan Sankt-Peterburga [The Strategic plan of St. Petersburg]. St. Petersburg: Proektnoe buro 'Strategicheskij plan dlja Sankt-Peterburga' 1998.

[19] Konceptsija General'nogo plana Sankt-Peterburga [Concept of the General plan of St. Petersburg] Available from: http://www.gov. spb.ru/Document/1089805744.doc
[20] Tchouikina S. Imidzhi Peterburga v presse (1998-2003) (Images of Petersburg in the media). Sankt-Peterburg v zerkale sotsiologii. St. Petersburg: Sotsiologicheskoe obschestvo im. M.M. Kovalevskogo 2003; pp. 59-79.

[21] Ippolitov A. Evropa na bullshit'e. Peterburgskie kartinki [Europe on the bullshit. Pictures of Petersburg]. Russkaya zhizn. 12 October 2007.

[22] Postanovlenie Pravitel'stva Sankt-Peterburga “O Peterburgskoj strategii sohranenija kul'turnogo nasledija" № 1681 [The Decree of the St. Petersburg government "On the St. Petersburg Strategy of cultural heritage preservation” № 1681] 1 November 2005.

[23] Chtoby sohranit skver u Kazanskogo, ego reshili zakryt' [To save the garden by Kazansky they decided to close it. Gazeta.spb.ru. 29 May 2008. Retrieved 2012 Oct 13] Available from: http://www.gaz eta.spb.ru/49923-0/

[24] Skver u Kazanskogo segodnja nachnut ogorazhivat' [Public garden by the Kazansky cathedral will be fenced in today]. 2009. Gorodskoy blog spb_ru. Available from: http://community.livejou rnal.com/spb_ru/3367812.html

[25] Banerjee T. The future of public space: beyond invented streets and reinvented places. J Am Planning Assoc 2001; 67(1): 9-24.

[26] Trubina E. Protesty i goroda [Protests and cities], russ.ru, March 2012. Available from: http://www.russ.ru/Mirovaya-povestka/Prote sty-i-goroda

[27] Kurennoy V. Urbanistiheskaya revolutsiya v Rosii [Urban Revolution in Russia]. Novaya Gazeta, 9 April 2012.

[28] Zhelnina A, Khokhlova A, Tykanova E, Pachenkov O. The right to the city. 2012. Available from: http://gaidarfund.ru/projects.php? chapter=project_club_discuss \&id $=143$

[29] Suvorov G. Obshestvo anonimnykh revolutsionerov [Society of the Anonymous Revolutioners]. slon.ru, March 2012. Available from: http://slon.ru/russia/obshchestvo_anonimnykh_revolyutsionerov765700.xhtml

(c) Anna Zhelnina; Licensee Bentham Open.

This is an open access article licensed under the terms of the Creative Commons Attribution Non-Commercial License (http://creativecommons.org/licenses/by$\mathrm{nc} / 3.0 /$ ) which permits unrestricted, non-commercial use, distribution and reproduction in any medium, provided the work is properly cited. 